\title{
The Factors That Influence Student Satisfaction on Loyalty Students at East Java
}

\author{
Dyah Eko Setyowati* \\ STIE Bisnis Indonesia \\ Jakarta, Indonesia \\ *dyahantariksa@gmail.com
}

\begin{abstract}
The research data used are primary data with a total of 231 students from a population of 479 active students at East Java, with a proportional random sampling technique. The analytical tool used is path analysis. The results of this study, IPIEMS student responses agreed and were satisfied with the reliability, responsiveness, certainty, empathy, and tangibility of student satisfaction and impact on the loyalty of IPIEMS students. Some of the things that become one of the main supports of the students agree and are satisfied are the understanding, sensitivity of staff, promises given, teaching and learning process services, attention of IPIEMS staff, and physical aspects of IPIEMS. While what makes students loyal to IPIEMS is because of the ability of IPIEMS to devote attention to what is needed to retain IPIEMS students. From the results of research in the E-learning era and the digital era 4.0 at this time, direct service is still needed to keep students loyal.
\end{abstract}

Keywords-reliability, responsiveness, certainty, empathy, tangible, and student loyalty

\section{INTRODUCTION}

In the current era of disruption there is a paradigm shift that is giving birth to knowledge management which is seen as more powerful as an important resource which is a prerequisite for creating competitive advantage for individuals, units, departments and organizations. This makes Indonesia must try to improve the quality of human resources and improve the competitiveness of Indonesian workers to be able to survive amid the era of free trade, and the digital era. The Indonesian government has focused and is concerned with labor issues and is working to create a climate that is conducive to accelerating the movement of economic growth through human resources. Employee knowledge is important toward customer service. Employee who has good or enough knowledge could explain and solve customer problem. This knowledge is practiced when the employee informs, handle complaints, and give other services to the customers [1]

The improvement can be done by increasing education, equitable distribution of education, improving health, providing training to the workforce, providing adequate facilities, improving non-formal educational institutions and others - will encourage the quality of the workforce. When a country has high competitiveness and is able to compete in the regional and global arena, it is certain that its human resources will be able to compete. IPIEMS as a non-formal institution has been a partner for 20 years as a formal educational institution, because IPIEMS as a tutoring institution, helped prepare Indonesian HR to become superior HR.

\section{LITERATURE REVIEW}

Service Quality has strategic role for gaining competitive advantage. It's difficult to differentiate product in banking industry, so service quality become one of the attributes to distinguish bank from another bank. High quality of services enable bank achieving competitive advantage [2]

There are many definitions and concept about service quality. Most of previously studies revealed that satisfaction is the result of a process of comparison between customer's expectations and perceptions of performance [3]. When customers perceive about many kinds of service attributes, it means that they evaluate about quality of services.

Identifying SERVQUAL dimensions into five aspects as follows: Tangibility: Physical facilities, equipment, and personnel appearance. Reliability: Able to perform the promised service properly and accurately. Responsiveness: Willingness to help customers and provide prompt service. Assurance: Knowledge and politeness of employees, as well as their ability to convey trust and confidence. Empathy: Caring, individual attention given by service providers to their customers [4]. SERVQUAL model is chosen to measure service quality because it could portrait service dimensions and it could be measured based on the banking service customer perspective [5].

\section{A. Quality of Service}

The quality of service is how well the service level provided has been in line with customer expectations. Quality services mean that the service has consistently matched customer expectations [6]. In his research on the quality of service in the field of bus transportation in Taiwan Taipei, defines the quality of service in the field of transportation in four dimensions. First, interactions with passengers, it refers to the respect and attention of service providers when interacting 
with passengers, and how they respond to the problems the passengers face. Secondly, tangible service equipment, related to the level of convenience of facilities and equipment operated by service providers. Third, convenience of service, convenience services related to accessibility, information provided, and the convenience of service networks [4].

The sampling techniques in this study use convenience sampling, as stated by Greener (2008), "Sample is chosen for ease or convenience", meaning that research sampling is based on an element of ease to Get samples. The questionnaire was deposited to the employees of IPIEMS, given in student to be filled. Quality of service is a measure of how well the service level provided has been in accordance with customer expectations. Quality services mean that the service is consistently in the customer's expectation [6].

\section{B. Loyalty}

Loyalty of a person will be products or services offered by the company. Loyalty itself is a continuation of the concept of customer satisfaction after consumers use products or services from the company $[1,7]$.

Customer loyalty can be measured from several indicators, namely: 1) makes regular repeat customer, indicating that customers are doing purchaser repeatedly on the company in a certain period is a loyal customer; 2) Purchases across product service lines, loyal customers do not just buy a single product but also buy a line of products and other services in the same company, 3) refer others, a loyal subscription will always recommend Peng Their positive experiences about product and company services to nearby people in order to buy in the same place and not buy elsewhere; 4) Demonstrates an immunity to the pull of the competition, loyal customers will not affect the influence of the competitors, because the loyal customers have had their own belief in the ability and the wait LAN from the Company [8].

\section{Customer Satisfaction}

Satisfaction is emotions based feeling, the level of pleasure and satisfaction, and the distance between performance and hope in the service. Contentment is the level of a person's feelings after comparing performance or results he felt compared to his expectations [7].

The hypothesis in this study is as follows [9]:

- H1: The reliability dimension has a positive effect on the loyalty of Tutoring Students through the satisfaction of Tutoring Students

- H2: The responsiveness dimension has a positive impact on the loyalty of Tutoring Students through the satisfaction of Tutoring Students

- H3: The certainty dimension has a positive impact on the loyalty of Tutoring Students through the satisfaction of Tutoring Students
- H4: The empathy dimension has a positive impact on the loyalty of Tutoring Students through the satisfaction of Tutoring Students

- H5: Intangible dimension has a positive impact on student loyalty IPIEMS tutoring through student satisfaction IPIEMS tutoring.

Factors Affecting IPIEMS Tutoring Student Satisfaction and its Impact on IPIEMS Tutoring Student Loyalty.

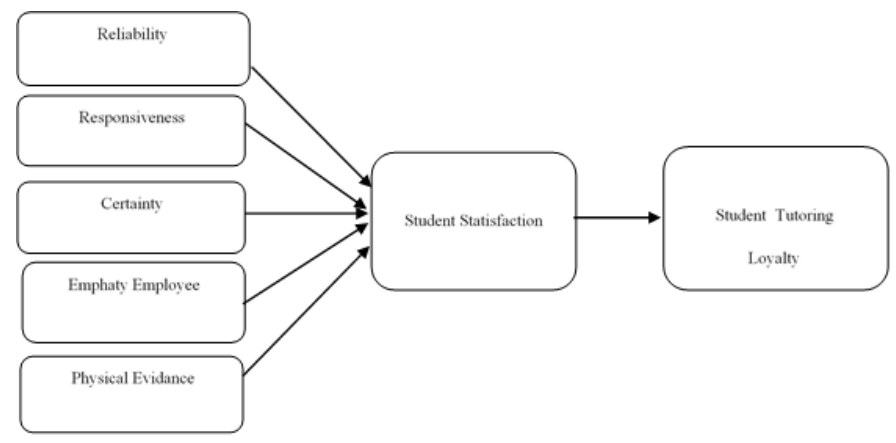

Fig. 1. Conceptual paper.

\section{METHODS}

This study use survey methodology using questioner as the instrument to gather data. Variables were measured by Likert scale with five categories of responses ranging from strongly disagree (score 1) to strongly agree (score 5) where respondents were asked to indicate the level of agreement or disagreement with some statements related to the object [10].

In this study, the authors chose to use proportionate stratified random sampling technique, because the sampling technique is in accordance with the distribution of population and samples based on grade / strata level. Proportionate stratified random sampling is sampling from members of the population randomly and proportionally distributed, this sampling is done if the population members are heterogeneous (not the same type). As for the method of sampling per stratum, the author uses the lottery method by writing the name of the population per stratum on each small paper, then folded. Sampling will be taken at random as a lottery and taken as many samples as specified. The paper drawn will be the sample number to represent the population. The sample in this study was 231 , the population was 429 .

\section{RESULTS AND DISCUSSION}

\section{A. Results}

Partial hypothesis test ( $\mathrm{t}$ test) found 4 (four) variables factors of satisfaction of Student Guidance that affect the satisfaction of IPIEM Student Guidance namely reliability (X1), certainty (X3), empathy (X4), and tangible (X5) . This proves to the reliability variable (X1) about the ability and the Tutor to provide teaching process services, consistent, and curriculum that suits the needs and expectations of students. 
For certainty variable (X3) about efforts to provide certainty for services, staff, and tutors to generate trust in promises. Next to the empathy variable (X4) about the understanding and sensitivity of Student Tutoring to the satisfaction of Student Tutoring. As for the tangible variable (X5) about the physical aspects of the IPIEMS Learning Institution building, it has an influence on the satisfaction of Tutoring Students. Whereas for the satisfaction of Tutoring Students $(Z)$ had an impact on the loyalty of Tutoring Students partially from the test results $(t$ test) had a positive impact on the satisfaction of Tutoring Students on the loyalty of Tutoring Students.

This shows that Tutoring Students are satisfied with the ability of Employees to give the attention needed to maintain Tutoring Students and then continue to do so. So that Tutoring Students can increase their loyalty. There is a significant influence Quality of Service (X) to customer loyalty (Y). On the beautiful research of Irjanti, Tampi, Mukuan found, reliability, responsiveness, assurance, and empathy, partial effect, unless physical evidence has no effect. Therefore, the clinic should be made beautiful [11]. Meanwhile, in the research of Yulia Larasati Putri, the direct and indirect effect of quality service influence on customer loyalty, Dian Comp Ambaraw [12]. There is 1 (one) variable, that is the responsiveness of Employees (X2) which does not affect the satisfaction of Tutoring Students. IPIEMS employee responsiveness variable (X2) about IPIEMS Tutoring employee responses in listening and addressing Tutoring Students' complaints did not affect the satisfaction of Tutoring Students.

\section{B. Discussion}

Path Analysis. The F count value is 142,305 with the Sig. 0,000 and a Fable value of 2.14. Because the value of $F$ count (142.305)> F table (2.14) with sig. smaller than 0.05 , it can be concluded that the regression equation model formed is fit or fit criteria. Which means the influence of factors - satisfaction of Student Guidance (X1, X3, X4 and X5) on the satisfaction of Student Guidance.

When viewed from the results of testing the determination of the factors that influence the satisfaction of Student Tutoring contained in the primary data it is known that the coefficient of determination (R2) is $71.7 \%$. With the results of the coefficient of determination it can be concluded that the satisfaction of Student Tutoring is $71.7 \%$ influenced by the factors of Student Tutoring satisfaction consisting of reliability (X1), certainty (X3), empathy (X4), and tangible (X5) while the remaining $53.7 \%$ is contributed by other factors that can be explained by other variables outside the model. Other factors outside the model such as instinctual factors and extrinsic factors include high achievement, student's expectations and talents, while extrinsic factors are the quality of tutors teaching, school culture, and school climate. For testing the determination of the satisfaction of Tutoring Students have an impact on the loyalty of Tutoring Students there is a coefficient of determination (R2) of 45\% satisfaction of Tutoring Students having an impact on the loyalty of Tutoring Students. The remaining $74.1 \%$ is influenced by other factors outside the model such as service quality, costs that are too high and causes disappointment in Student Tutoring.

From the direct and indirect influence in this study found the greatest influence on the satisfaction of Tutoring Students is $35.2 \%$ influence of empathy (X4) on the satisfaction of Tutoring Students $(Z)$, in this case understanding and sensitivity towards Tutoring Students the biggest influence on the satisfaction of Student Tutoring. While in the second place is $22.6 \%$ certainty influence (X3) on the satisfaction of Student Guidance (Z), which means efforts in providing certainty over the service of Student Guidance Students become the second largest influence. The third rank is $11.8 \%$ the effect of reliability (X1) on the satisfaction of Student Guidance (Z), the teaching and learning process, is consistent and the curriculum given by the Tutor occupies the third position. For the fourth rank of $11.5 \%$ tangible influence (X4) on the satisfaction of Student Guidance ( $\mathrm{Z}$ ), the physical aspects of the building became the fourth influence in this study. While the overall effect $(X 1, X 2, X 3, X 4, X 5)$ on the satisfaction of Tutoring Students (Z) was $81.1 \%$. And the effect of satisfaction of Tutoring Students $(\mathrm{Z})$ on the loyalty of Tutoring Students (Y) is $44.9 \%$, which means that the satisfaction of Tutoring Students is important in maintaining the loyalty of Tutoring Students. To test hypotheses 8 through 12 that explain the effect of each variable indirectly can be explained in the following table 1 .

TABLE I. INDIRECT EFFECTS

\begin{tabular}{|l|l|l|}
\hline & \multicolumn{1}{|c|}{ Indirect Effects (Z) } & \multicolumn{1}{c|}{ Decision } \\
\hline $\mathrm{H}_{1}: \mathrm{PX}_{1} \mathrm{Y}$ & $0,11 / 11 \%$ & H1 Accepted \\
\hline $\mathrm{H}_{2}: \mathrm{PX}_{2} \mathrm{Y}$ & - & H2 Rejected \\
\hline $\mathrm{H}_{3}: \mathrm{PX}_{3} \mathrm{Y}$ & $0,181 / 18,1 \%$ & H3 Accepted \\
\hline $\mathrm{H}_{4}: \mathrm{PX}_{4} \mathrm{Y}$ & $0,271 / 27,1 \%$ & H4 Accepted \\
\hline $\mathrm{H}_{5}: \mathrm{PX}_{5} \mathrm{Y}$ & $0,107 / 10,7 \%$ & H5 Accepted \\
\hline
\end{tabular}

Source: data processing

Testing the path coefficient of influence indirectly through the satisfaction of Student Tutoring: H1: 11\% of the effect of reliability (X1) on the loyalty of Tutoring Students (Y) through satisfaction of Tutoring Students (Z). From the calculation results for the hypothesis (Ha1), "The reliability dimension (X1) has a positive impact on the loyalty of Tutoring Students (Y) through the satisfaction of Tutoring Students (Z)", accepted; H2: Capability (X2) to the loyalty of Tutoring Students (Y) through the satisfaction of Tutoring Students (Z). From the calculation results, for the hypothesis (Ha2), "The dimension of responsiveness (X2) through satisfaction of the Student Guidance $(Z)$ " was rejected. because in sub-structure 1 the path coefficient results are not significant; H3: As much as $18.1 \%$ influence of certainty (X3) on the loyalty of Tutoring Students (Y) through the satisfaction of Tutoring Students (Z). From the calculation results for the hypothesis (Ha3), "The certainty dimension (X3) has a positive impact on the loyalty of Tutoring Students (Y) through the satisfaction of Tutoring Students (Z)", accepted; H4: 27.1\% influence of empathy (X4) on the loyalty of Tutoring Students (Y) through the satisfaction of Tutoring Students (Z). From the calculation results, the hypothesis (Ha4), "The empathy dimension (X4) has a positive 
impact on the loyalty of Tutoring Students (Y) through the satisfaction of Tutoring Students (Z)", accepted; H5: 10.7\% of tangible influence (X5) on the loyalty of Tutoring Students (Y) through satisfaction of Tutoring Students (Z). From the calculation results, the hypothesis (Ha5), "Intangible Dimension (X5) has a positive impact on the loyalty of Tutoring Students (Y) through satisfaction of Tutoring Students (Z)", was accepted. From this study, get the first 2 (two) structural equations found from the results of sub-structure 1, namely the satisfaction of Student Guidance $(\mathrm{Z})=0.164$ reliability $(\mathrm{X} 1)+0.27$ certainty $(\mathrm{X} 3)+0.405$ empathy of Employees (X4) $+0,159$ tangible $(\mathrm{X} 5)+0,537(\varepsilon 1)$. The second structural equation from the results of sub-structure 2 namely loyalty of Tutoring Students $(Y)=0.67$ satisfaction of Tutoring Students $(Z)+0.741(\varepsilon 2)$.

\section{CONCLUSION}

The results of this study, IPIEMS student responses agreed and were satisfied with the reliability, responsiveness, certainty, empathy, and tangibility of student satisfaction and impact on the loyalty of IPIEMS students.

\section{REFERENCES}

[1] N. Bouranta, E. Psomas, M.F. Suárez-Barraza and C. Jaca, "The key factors of total quality management in the service sector: a cross-cultural study," Benchmarking, vol. 26, no. 3, pp. 893-921, 2019.
[2] R. Harimurti and T. Suryani, "The Impact of Total Quality Management on Service Quality, Customer Engagement, and Customer Loyalty in Banking,” J Manaj dan Kewirausahaan, vol. 21, no. 2, pp. 95-103, 2019.

[3] B.Y. Reza Shayestehfar, "Bank service quality: A comparison of service quality between BSI branches in Isfahan and Dubai," TQM J, vol. 31, pp. 28-51, 2019.

[4] Hsin-Hui Lin, "The effect of multi-channel service quality on mobile customer loyalty in an online-and-mobile retail context," Serv. Ind. J.

[5] A. Fauzi and T. Suryani, "Measuring the effects of service quality by using carter model towards customer satisfaction, trust and loyalty in Indonesian Islamic banking," J. Islam Mark., vol. 10, no. 1, pp. 269-89, 2019.

[6] T.B. Joewono and H. Kubota, User satisfaction with paratransit in competition with motorization in indonesia: anticipation of future implications, [Online]. Retrieved from: https://link.springer.com/article/10.1007/s11116-007-9119-7\%0D

[7] S.B. Indonesia, "Analysis of the Effect of Physical Evidence, Reliability , Responsiveness, Assurance, Emphaty, Toward Customer Satisfaction Lotte Mart in Jakarta, pp. 86-9, 2014.

[8] J. Griffin, Customer Loyalty: Menumbuhkan dan Mempertahankan Kesetiaan Pelanggan. Jakarta: PT Erlangga, 2005.

[9] K. Naresh and M. Malhotra, Marketing Research: An Applied Orientation. Sixth Edit. Pearson Education, 2010.

[10] A. Valarie, Zeithaml, Mary Jo Bitner DG. Services Marketing: Integrating Customer Focus Across the Firm. 7th ed. McGraw-Hill Education, 2017.

[11] K. Naresh and M. Malhotra, Marketing Research: An Applied Orientation. Sixth Edit. Pearson Education, 2010.

[12] Y.L. Putri and H. Utomo, "Pengaruh Kulaitas Pelayanan terhadap Loyalitas Pelanggan dengan Kepuasan sebagai Variabel Intervening (Studi Persepsi Pada Pelanggan Dian Comp Ambarawa)," Among Makarti. Vol. 10, no.19, pp. 70-90, 2018. 